\title{
TAX POLICY IN THE SLOVAK AND CZECH ECONOMIES*
}

\section{Zlatica Peňákováa}

\begin{abstract}
Today, society is struggling with the uncertainty caused by the pandemic of coronavirus disease 2019 (covid-19). Government budgets will face a real challenge in the coming years. This paper provides an overview of public finances and their condition over the past 20 years in the Slovak and Czech Republics. It investigates the possible effects of different tax type changes and also the option to cover budget losses. A simple dynamic stochastic general equilibrium (DSGE) model with three sectors was calibrated using data from 2018 and a stochastic analysis was performed. It was shown that the economy was more sensitive to shocks on social security contributions than to those on other taxes. The results may help support a reform of decreasing labour taxes, for which both Slovakia and Czechia have been waiting for a long time.
\end{abstract}

Keywords: Tax reform, Czech Republic, Slovakia, DSGE, labour, capital, consumption JEL Classification: C50, E60, H20

\section{Introduction}

At the end of the previous millennium, the world economy experienced a period of boom and relative stability. Since 2000, however, it has faced many challenges and tests. The first fluctuations were caused by bubbles on the stock and mortgage markets, which turned into a global financial and economic crisis associated with a multi-percentage-point economic downturn. On top of that, EU member countries subsequently had to deal with the debt crisis. During the second decade, the world economy has slowly recovered into a relatively long period of continuous growth.

In recent years, we saw a number of predictions of a coming recession, but no one expected the cause that actually triggered the current decline in growth. Nowadays, economies are struggling with the uncertainty brought by the pandemic of covid-19. Restrictive

\footnotetext{
* Supported by funding of specific research at the Faculty of Economics and Administration, project MUNI/A/0906/2019. This support is gratefully acknowledged.

a Masaryk University, Faculty of Economics and Administration, Czech Republic

E-mail: penakova.zlatica@mail.muni.cz
} 
measures have caused a reduction in economic activity and some sectors have been shut down completely. This epidemic on such a large scale highlights the crucial role of the state, which has not only put in place measures against the spread of the virus, but also made proposals to address its economic impact. The role of the government has thus been strengthened again at the expense of the market.

As economic subjects turn their attention to the government and ask for help and compensation for restrictions on their activities, government budgets will face a real challenge in the coming years. In addition to the current high demand for spending and the decline in income caused by the pandemic, developed countries have been experiencing a trend of population ageing, which implies future increases in spending on social and health care.

In this paper, we will examine the effects of fiscal policy on the economy using a simple dynamic stochastic general equilibrium (DSGE) model. According to the OECD (2010), direct taxes have the greatest negative effect on the economy and a reduction in such taxes might have a positive (stabilizing) effect. A shift from direct to indirect taxation has been the main fiscal policy trend in recent years, and its growth-invoking effect was also confirmed by Mamatzakis (2005). In our work, we will pay attention to the environments of the Slovak and Czech economies, which are close for historical reasons. They formed a sovereign state beginning in 1918 in which, apart from one break, they remained until the end of 1992. They still have many common and similar parameters, but they currently have different monetary policy limitations as Slovakia is a member of the eurozone and faces the specifics of a single monetary policy.

Both countries have active fiscal policies and have still relatively high labour taxes in the EU (consisting of income and social security contribution taxes) with room for reductions. As calculated by the European Commission (2020b), the implicit tax rate on labour was $43.83 \%$ for Slovakia and $40.61 \%$ for Czechia in 2018 , which is the first and the seventh highest rate, respectively, among the EU member states. One of the tax reforms promised by the Czech government at that time was a decrease in direct labour taxes. The reform had been implemented in 2021. The aim of this paper is to examine the current condition of public finances and the possible effects of decreasing different taxes on labour and capital in the Slovak and Czech Republics. At the same time, it will investigate whether consumption taxes might help balance the budget and compare results while keeping in mind the different monetary policy limitations.

Taxes are an essential part of the economy and as such they are subject to numerous studies. Some of them investigate the overall effect of taxation on economic growth, welfare or income distributions, while others examine effects of different types of taxes. Due to the negative impact of taxation on economy, it is also important to measure the size of the impact. Besides standard tax burden measurements, the research also offers a variety 
of alternative approaches that try to eliminate disadvantages connected to standard indicators; see, e.g., Kotlán et al. (2011).

The present paper is inspired by the work of Costa Junior and Sampaio (2014), who investigated and evaluated direct tax reduction policies within the productive sector in Brazil using a small DSGE model. The chosen model is quite simple in order to preserve the interpretability of the results. It follows on and extends the previous research presented in Konôpková (2017). To provide a complex overview of the economic situation, the next section of the paper addresses the latest trends in the Slovak and Czech Republics and the European Union (EU), the political and economic union of which both countries are members. The third section briefly introduces the individual components of the modified DSGE model used initially by Costa Junior and Sampaio (2014). The original model is adjusted for shocks in consumption and property taxes so that all taxes in the economy can be examined for changes. The next part presents the results, a comparison of the effects of changes in different tax types. Finally, the responses of economic variables to negative shocks in social security contributions (labour taxes) are discussed. At the same time, the option to cover/offset budget losses is examined. Due to data availability, the simulation and impulse response functions start in 2018.

\section{Recent Trends}

Deepening of globalization is typical of the world economy in the third millennium. Individual countries are becoming more and more specialized in areas in which they have a competitive advantage. Developed economies face various challenges, one of which is surely unfavourable demographics. The problem of an ageing population increases demand on future spending and puts pressure on the consolidation of public finances.

Figure 1 shows the population structure in the EU, Slovakia, and Czechia together with the median age. Over the past 20 years, the share of the population under 65 has decreased, also the age bracket eligible for work (15-64) has fallen. On the contrary, the proportion of people over 65 in the EU population has increased. Both Slovak and Czech populations are catching up with the ageing trend of the European population and soon might overtake it. Although the median age is still lower, the rate of change over the past 20 years has been more intense. The structure of the Czech population almost copies the EU, but the change dynamics are more severe. The segment of active population is decreasing almost twice faster. Unfortunately, population models do not predict a change in future trends, and so governments will have to deal with this structural change and prepare effective reforms of their social, health, and pension systems. 
Figure 1: Population structure in 2019 and change from 2000

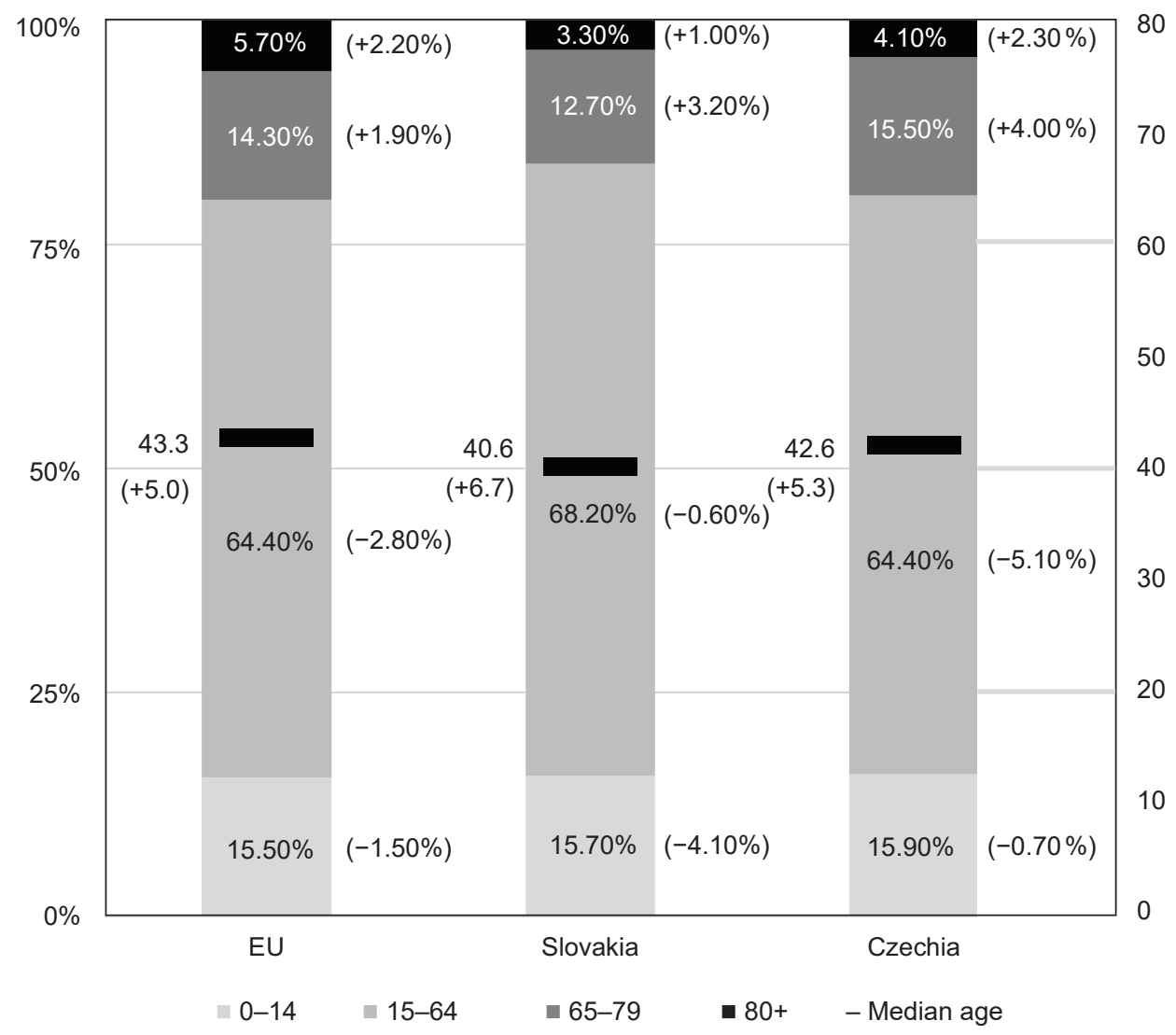

Source: Based on data from Eurostat (2020c)

Public finances still have not fully recovered from the last global financial crisis. The crisis has brought not only a decline in the performance of economies, but probably also changes of a more long-term nature. It is still not clear how much the measures taken by governments, whether positive or negative, have also changed the nature of the economy.

In response to the crisis, the EU had its biggest decline in GDP in 2009. After a small economic recovery during the next year, the EU fell into recession again two years later. The reason was a debt crisis among its members caused by issues in Greece. The crisis development of GDP growth in Czechia and Slovakia was similar but more intense, Slovakia experienced only one continuous period of decline at the beginning, and in the near 
post-crisis periods GDP growth slowed but did not decline. Neither the Czech nor the Slovak economy have yet reached their pre-crisis growth levels, and it rather appears that they are gradually converging with other lower-growth European countries. For more detailed data, see Eurostat (2020b).

\section{Figure 2: Development of debt (\% of GDP)}

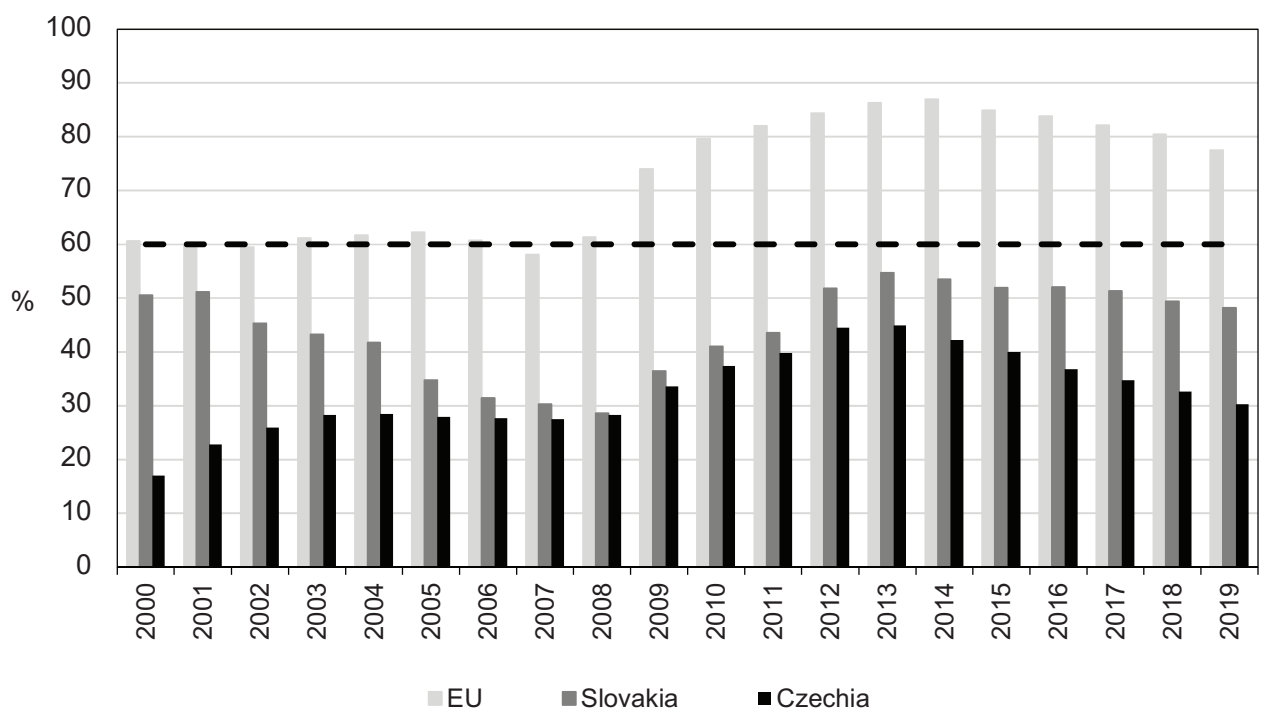

Source: Based on data from Eurostat (2020b)

The crisis revealed the weak condition of European public finances. Figures 2 and 3 display their development. After 2008, the debt-to-GDP ratio of EU members increased significantly and thanks to economic growth, it has been declining in recent years. Compared to the pre-crisis period, it is still around 20 percentage points above the target. Slovakia is copying this trend, despite the fact that in the pre-crisis period it had achieved a significant reduction in its debt-to-GDP ratio. In contrast, the development of the debtto-GDP ratio in the Czech Republic is more stable, but with lower values. The issue of public debt sustainability has been addressed by a number of research papers. It remains questionable what size of debt can cause stability issues for countries and also whether the absolute or relative size (to GDP) of debt plays a key role in the performance and final outcome of the economy. The debt crisis is closely related to the government's budget performance and its yearly balance. 
Figure 3: Development of cyclical deficits (\% of GDP)

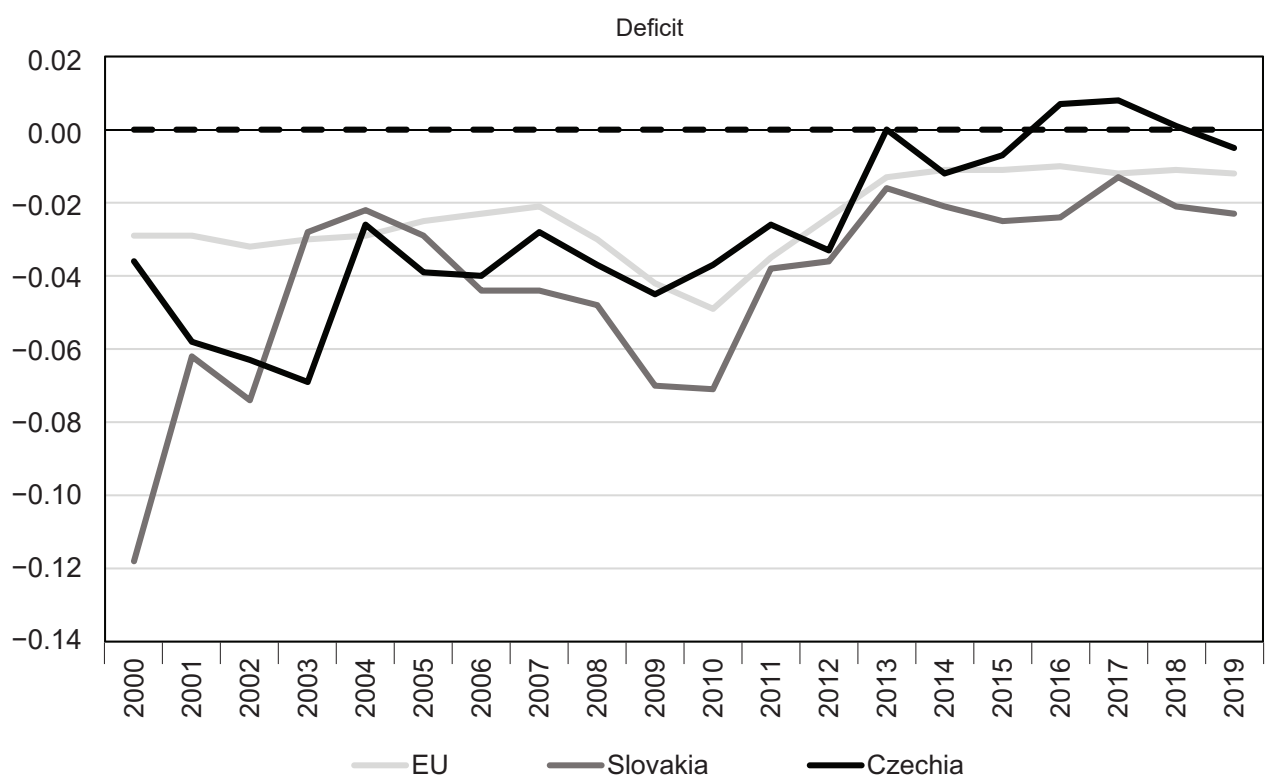

Source: Based on data from European Commission (2020a)

Figure 3 shows that in the pre-crisis period a cyclical public budget deficit of several percentage points was the absolute standard, even during the years of the greatest boom. In 2003, the average deficit among EU countries was 3.0\% and a budget surplus was recorded by only 4 members. In response to the debt crisis and budget issues, in 2012, European countries signed the Treaty on Stability, Coordination and Governance in the Economic and Monetary Union, also known as the Fiscal Compact. The agreement strengthens the text of the Stability and Growth Pact, introduces a mandatory balanced budget rule, and moves members closer to fiscal integration. In 2019, $16 \mathrm{EU}$ member states were already experiencing a budget surplus including Czechia, which signed the Treaty only that year after its initial refusal. Unfortunately, Slovakia is still waiting for its first at least balanced budget. The plan was postponed every year, and, due to the current coronavirus crisis, it will not happen soon.

Considering the trends described above, consolidation of the public sector is the second key task for the government to be implemented, right after fighting the current crisis. The number of observed unfavourable situations creates considerable pressure on economic policy options to stabilize the economy. Given the consequences of the last global stagnation ten years ago, justified doubts have arisen whether classic tools can help the economy. The governments of both countries are active in their economic policy and apply a wide 
range of discretionary tools in line with the standard Keynesian approach, but with different results and progress. What is behind the difference in policy? In addition to the different political cycles after the split of the countries, one of the reasons might be the different monetary policy limitations. Both countries joined the EU in 2004, but Slovakia also joined the monetary union in 2009. In order to be successful in the accession process, the Slovak government was forced to consolidate its national finances strictly even if the economy was below its potential output. In the years after the crisis, the government was also committed by the Fiscal Compact to conduct another massive consolidation, which seems to have been rather destabilizing for Slovakia and has not yet brought the desired results.

After the pandemic crisis, both countries will need to deal with debt created by current support measures, which indicates new consolidation packages on spending to be implemented. The governments might also focus on the revenue side of the national budget and enact tax reforms to boost the economy. As already mentioned, an appropriately chosen mixture of taxes might invoke economic growth. Both countries still have relatively high labour taxes (consisting of income and social security contribution taxes). According to the OECD (2020), the average personal income tax and social security contribution rates on gross labour income was continuously increasing over the past decade, with a value of around $24-25 \%$ in 2019 . There is definitely room for a decrease in labour taxes, which is also one of the tax reforms promised and implemented in Czechia.

\section{Methodology and Data}

The DSGE approach has been a key macroeconomic modelling approach in recent years and was developed in order to make economic models more immune to the Lucas critique (1976). It is hard to identify the first DSGE model as the progress from neo-Keynesian modelling was slow and gradual, but it is worth noting the introductory and most-cited book by Galí (2008) on DSGE modelling. After the crisis in 2008, special attention has also been paid to fiscal policy as it seems that monetary policy can no longer be effective. To mention some recent work on tax policy, Alves (2018) developed a DSGE model to examine the impacts of different types of taxes. Kim and Kim (2018) used a DSGE model to study the welfare implications of a simple operational tax policy rule for different types of taxes. Algozhina (2012) introduced a DSGE model for joint fiscal and monetary interactions, investigating changes in public investment and consumption.

The modelling has been characterized by a high rate of knowledge transfer, where notably small economies take over models prepared by big or developed countries. Researchers, central banks, and ministries of finance have developed their own DSGE models to explain various situations in the economy and to predict reactions to future decisions or unexpected shocks, which is also the case of Slovakia and the Czech Republic. 
Zeman and Senaj (2009) introduced a medium-sized DSGE model for Slovakia (developed based on the model by Cuche-Curti et al. (2009) for the Swiss economy) to study four different shocks: monetary policy loosening, expansionary fiscal policy, and shocks in productivity and oil prices. The model has a rather stylized representation of the fiscal side. Therefore, Múčka and Horváth (2015) introduced a DSGE model (using the model by Pytlarczyk (2005) for the German economy) considering an array of fiscal instruments presented on the revenue and expenditure sides. The Czech Ministry of Finance is developing its own model called Hubert in order to evaluate the situation in the economy, prepare policy and make decisions. The model was first introduced by Štork et al. (2009) and has been continuously extended; see $e$. g.,Aliyev et al. (2014). The Czech National Bank is preparing its own core g3 model described in Andrle et al. (2009), which has been variously modified. Ambriško et al. (2015) offer a fiscal extension of the model.

The model used in this study is designed for the environment of a small economy with three sectors - households, firms and government (authority) - and the equilibrium condition on the goods market holds true:

$$
Y_{t}=C_{t}+I_{t}+G_{t} \text {. }
$$

\section{Households}

Two types of representative agents - active (Ricardian households) and inactive (non-Ricardian households) workers with a fixed split - comprise the entire household sector. If $C_{R, t}\left(C_{N R, t}\right)$ is the consumption of Ricardian (non-Ricardian) households, then the aggregate consumption $\mathrm{C}_{t}$ of individuals can be expressed as:

$$
C_{t}=(1-\omega) C_{R, t}+\omega C_{N R, t} .
$$

Active workers are taxpayers, contributors to the pension system, and also savers. This type of household maximizes the intertemporal utility function by choosing consumption, savings, investments and leisure.

Let $E_{t}$ be the expectation operator, $\beta \in(0,1)$ the intertemporal discount factor, $L_{t}$ labour, $S_{t}^{C}, S_{t}^{L}$, shocks on intertemporal consumption and the labour supply, $\psi$ the marginal disutility of labour, and $\sigma$ the coefficient of relative risk aversion, and then the maximization problem of a Ricardian household is:

$$
\max E_{t} \sum_{t=0}^{\infty} \beta^{t} S_{t}^{C}\left[\frac{C_{R, t}^{\sigma}}{1-\sigma}-S_{t}^{L} \frac{L_{t}^{1+\psi}}{1+\psi}\right] .
$$

A household's savings can be made in the form of investment into capital goods $I_{t}$ or the purchase of bonds issued by the government $B_{t+1}$ with the rate of return $R_{t}^{B}$. Every 
household must pay taxes on consumption $\tau_{c}$, labour income $\tau_{l}$ capital income $\tau_{k}$ and social security contributions $\tau_{p}$. $\phi_{t}^{i}$ are the stochastic components of taxes. Households receive wages $W_{t}$ for labour, return from capital $R_{t}$ and payments from those bonds $B_{t}$ that matured after a given period. The budget constraints on a given household are then:

$$
P_{t}\left(1+\frac{\tau_{c}}{\phi_{t}^{c}}\right)\left(C_{R, t}+I_{t}\right)+\frac{B_{t+1}}{R_{t}^{B}}=W_{t} L_{t}\left(1-\frac{\tau_{l}}{\phi_{t}^{l}}-\frac{\tau_{p}}{\phi_{t}^{p}}\right)+R_{t} K_{t}\left(1-\frac{\tau_{k}}{\phi_{t}^{k}}\right)+B_{t} .
$$

The capital in economy is characterized by the law of motion:

$$
K_{t+1}=(1-\delta) K_{t}+I_{t} .
$$

Shocks presented to the model follow the rules of movement:

$$
\begin{aligned}
& \log S_{t}^{C}=\left(1-\rho_{s c}\right) \log S_{s s}^{C}+\rho_{s c} S_{t-1}^{C}+\epsilon_{s c, t} \\
& \log S_{t}^{L}=\left(1-\rho_{s l}\right) \log S_{s s}^{L}+\rho_{s l} S_{t-1}^{L}+\epsilon_{s l, t} \\
& \log \phi_{t}^{l}=\left(1-\rho_{l}\right) \log \phi_{s s}^{l}+\rho_{l} \phi_{t-1}^{l}+\epsilon_{l, t} \\
& \log \phi_{t}^{k}=\left(1-\rho_{k}\right) \log \phi_{s s}^{k}+\rho_{k} \phi_{t-1}^{k}+\epsilon_{k, t} \\
& \log \phi_{t}^{c}=\left(1-\rho_{c}\right) \log \phi_{s s}^{c}+\rho_{c} \phi_{t-1}^{c}+\epsilon_{c, t} \\
& \log \phi_{t}^{p}=\left(1-\rho_{p}\right) \log \phi_{s s}^{p}+\rho_{p} \phi_{t-1}^{p}+\epsilon_{p, t}
\end{aligned}
$$

where $\varepsilon_{i, t}$ is exogenous shock and $\rho_{i}$ is the autoregressive component.

Inactive workers are retired workers and are not allowed to create savings. They are limited by the value $P E N$ of the benefits received from the government and do not maximize their intertemporal utility function:

$$
P E N=\left(1+\frac{\tau_{c}}{\phi_{t}^{c}}\right) P_{t} C_{N R, t} .
$$

\section{Firms}

A final good in the economy $Y_{t}$ is created in two stages within the firm sector, where $Y_{j, t}$ is the intermediate product and $\varphi$ is the elasticity of substitution between intermediate goods. The following equation is used:

$$
Y_{t}=\left(\int_{0}^{1} Y_{j, t}^{\frac{\varphi-1}{\varphi}} d j\right)^{\frac{\varphi}{\varphi-1}}
$$


First, there is the wholesale sector representing the number of firms that produce different intermediate goods and face monopoly competition. With the share of capital $\alpha$ and productivity $A_{t}$, wholesalers determine the quantities of production factors to minimize costs taking their prices as given:

$$
\min _{L_{j, t} K_{j, t}} W_{t} L_{j, t}+R_{t} K_{j, t},
$$

subject to the equation

$$
Y_{j, t}=A_{t} K_{j, t}^{\alpha} L_{j, t}^{1-\alpha} .
$$

When $\varepsilon_{A, t}$ is exogenous shock and $\rho_{A}$ the autoregressive component, the law of motion of technology is:

$$
\log A_{t}=\left(1-\rho_{A}\right) \log A_{s s}+\rho_{A} \log A_{t-1}+\epsilon_{A, t} .
$$

Firms maximize their profit by subsequently determining the optimal price of the good and its quantity:

$$
\max _{P_{j, t}} P_{t} Y_{t}-W_{t} L_{j, t}-R_{t} K_{j, t}
$$

The second stage of production is performed by the retail industry represented by a single firm in perfect competition. The firm aggregates intermediate goods from wholesalers into a single good consumed by agents in the economy. Subject to the same equation as defined by (13), the firm maximize its profit taking the prices of goods from wholesalers as given:

$$
\max _{Y_{j, t}} P_{t} Y_{t}-\int_{0}^{1} P_{j, t} Y_{j, t} d j
$$

Prices in the economy are subject to change in line with Calvo's (1983) pricing. Only a randomly selected fraction $(1-\theta)$ of wholesalers is able to set the optimal price $P_{j, t}$ in every period. The remaining segment $\theta$ of firms can use the price from the previous period $P_{j, t-1}$. The overall price level in the economy is thus equal to:

$$
P_{t}=\left[\theta P_{t-1}^{1-\varphi}+(1-\theta) P_{t}^{1-\varphi}\right]^{\frac{1}{1-\varphi}} .
$$

\section{Government}

Government is the third sector in the model. It acts as one common fiscal and monetary authority and also takes care of the social security system in the economy. Only a simple social system with no capitalization is considered, so the pension balance $B A L_{t}$ is equal to the difference between revenues and expenses: 


$$
B A L_{t}=\frac{\tau_{p}}{\phi_{t}^{p}} W_{t} L_{t}-P E N .
$$

The fiscal authority needs to finance purchases of goods and services. Resources for its spending are accumulated from taxes and issued bonds, which also enables debt financing for the government.

Tax revenue is equal to:

$$
T A X_{t}=\frac{\tau_{c}}{\phi_{t}^{c}} P_{l}\left(C_{t}+I_{t}\right)+\frac{\tau_{l}}{\phi_{t}^{l}} W_{t} L_{t}+\frac{\tau_{k}}{\phi_{l}^{k}} R_{t} K_{t}
$$

and the public debt is given as:

$$
\frac{B_{t+1}}{R_{t}^{B}}-B_{t}=P_{t} G_{t}-B A L_{t}-T A X_{t} .
$$

The government's spending is relatively sensitive to the size of public debt with the sensitivity coefficient $\chi$. Let $G_{s s} B_{s s}$ be steady-state levels, and then the following equation holds:

$$
G_{t}-G_{s s}=\chi\left(B_{t}-B_{s s}\right)
$$

The monetary authority controls the interest rate using the simple Taylor (1993) rule with the goal of output growth and price stability. Let $a, b$ be the respective sensitivity coefficients, $\pi_{t}$ the inflation rate, and $Y_{s s}, R_{s s}^{B}, \pi_{s s}$ the steady-state levels, and so the rule is:

$$
R_{t}^{B}=a\left(Y_{t}-Y_{s s}\right)+b\left(\pi_{t}-\pi_{s s}\right)+R_{s s}^{B}
$$

\section{Results}

To perform a stochastic analysis, it is required to assign values to structural parameters. A summary of the parameters used for the Slovak and Czech economies together with their sources is provided in the Appendix. Individual values are obtained from the economic literature, other DSGE works, or statistics available for 2018. Risk aversion is set in line with Štork et al. (2009). Tax rates are calibrated using implicit tax, as it is standard in DSGE works and also done by Ambriško et al. (2015). Other than the different tax rates and population structures, the main difference between the setup of the countries is monetary policy. As Slovakia is member of a monetary union and cannot conduct its own monetary policy, the Taylor rule was removed by setting the sensitivity to inflation and interest to zero.

Stochastic simulations were conducted for exogenous unit shocks in tax rates on capital income $\varepsilon_{k, t}$, labour $\varepsilon_{l, t}$ and $\varepsilon_{p, t}$ (income tax and social security contribution tax), and 
consumption $\varepsilon_{c, t}$. The impulse response functions were generated for 50 periods. Table 2 presents the variance decomposition of the errors of the simulated endogenous variables in relation to the presented exogenous shocks for both countries.

Table 2: Variance decomposition (in percent)

\begin{tabular}{l|c|c|c|c|c|c|c|c|c}
\hline SK & Y & Welfare & C & I & K & L & TAX & B & G \\
\hline $\boldsymbol{\epsilon}_{\boldsymbol{k}, \boldsymbol{t}}$ & 1.2 & 2.2 & 2.8 & 3.2 & 3.0 & 0.5 & 3.6 & 4.1 & 4.1 \\
\hline $\boldsymbol{\epsilon}_{\boldsymbol{l}, \boldsymbol{t}}$ & 4.8 & 4.7 & 4.3 & 4.6 & 4.7 & 5.0 & 3.4 & 3.7 & 3.7 \\
\hline $\boldsymbol{\epsilon}_{\boldsymbol{p}, \boldsymbol{t}}$ & 88.4 & 85.03 & 78.5 & 84.2 & 85.0 & 90.6 & 72.5 & 67.5 & 67.5 \\
\hline $\boldsymbol{\epsilon}_{\boldsymbol{c}, \boldsymbol{t}}$ & 5.6 & 8.1 & 14.4 & 8.0 & 7.3 & 3.9 & 20.5 & 24.7 & 24.7 \\
\hline $\mathbf{C Z}$ & $\mathbf{Y}$ & $\mathbf{W e l f a r e}$ & $\mathbf{C}$ & $\mathbf{I}$ & $\mathbf{K}$ & $\mathbf{L}$ & $\mathrm{TAX}$ & $\mathbf{B}$ & $\mathbf{G}$ \\
\hline $\boldsymbol{\epsilon}_{\boldsymbol{k}, \boldsymbol{t}}$ & 3.3 & 5.0 & 5.5 & 7.2 & 7.2 & 3.0 & 6.0 & 6.5 & 6.5 \\
\hline $\boldsymbol{\epsilon}_{\boldsymbol{l}, \boldsymbol{t}}$ & 8.0 & 7.5 & 6.8 & 7.3 & 7.4 & 8.2 & 5.6 & 5.9 & 5.9 \\
\hline $\boldsymbol{\epsilon}_{\boldsymbol{p}, \boldsymbol{t}}$ & 78.6 & 74.2 & 66.7 & 72.1 & 73.2 & 80.9 & 61.4 & 58.0 & 58.0 \\
\hline $\boldsymbol{\epsilon}_{\boldsymbol{c}, \boldsymbol{t}}$ & 10.1 & 13.3 & 21.0 & 13.4 & 12.2 & 7.9 & 27.0 & 29.6 & 29.6 \\
\hline
\end{tabular}

Source: Author's calculation

Overall, we can conclude that the shock presented in the tax rate on social security contributions was the most effective, influencing the economy highly compared to shocks in the other tax rates. The shock in the capital income tax rate had almost no effect compared to the others. The shock in consumption taxes had a significant effect on consumption and also on variables connected to the government's budget, which suggests the suitability of consumption taxes to stabilize the budget without a large effect on other sectors in the economy.

Figure 4 shows the impulse responses of chosen economic variables to a negative unit shock in social security contributions (labour taxes) for each country. All in all, we can briefly summarize that the reactions of the variables were in line with expectations and positive, increasing welfare in the economy. Lower contribution taxes increase the disposable income of households and motivate them to work more as they make leisure time more expensive. Their work boosts the economy and creates more output, which supports consumption and investment. 
Figure 4: Impulse response function for shocks in social security contribution taxes
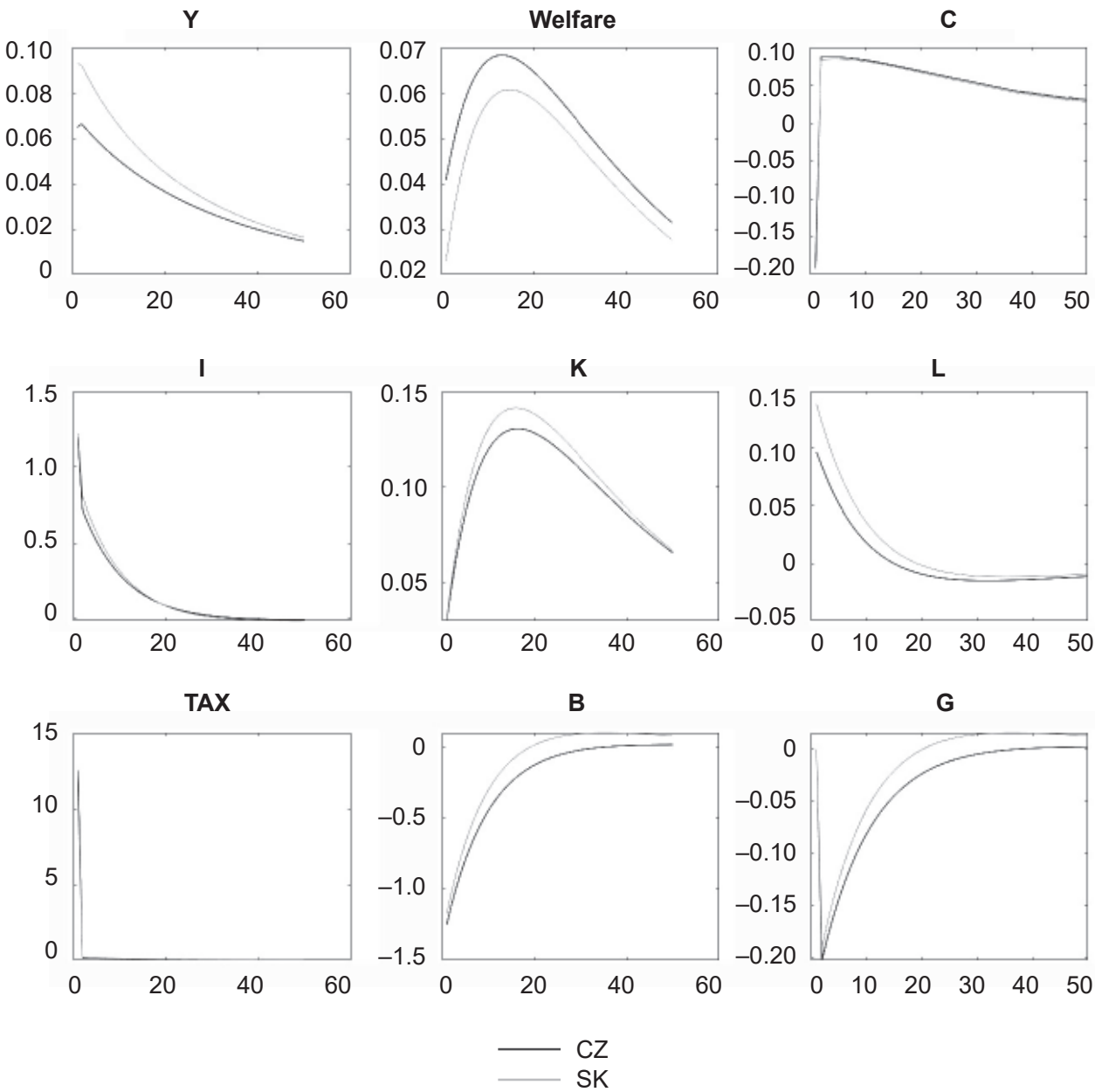

Source: Author's construction

Despite the reduction policy, thanks to the changes in the behaviour of the economic subjects, simulated tax revenue did not seem to be significantly affected. The fall in simulated debt was greater than the decline in government spending, which suggests that a reduction in labour taxes can help the government consolidate public finances for the long term.

Consumption in the economy is a composition of Ricardian and non-Ricardian households. Active workers increase their consumption thanks to the direct substitution effect 
of the labour tax decline. On the other hand, inactive workers are restricted by payments from the government and are forced to reduce their consumption due to a decline in government spending, which is reflected in a sharp downturn at the beginning of the simulation.

Investments responded positively to this type of shock, again more intensely to a reduction in labour income taxes. Thanks to greater disposable income, investments increased, which enabled creating more capital and additionally supported economic growth. The positive change slowly vanished due to the diminishing marginal product of capital and the displacement effect of government spending, which pushes investment out of the economy.

The Slovak economy was more sensitive to the shock than the Czech economy. A country without its own monetary policy can rely only on its fiscal policy, and it is a good sign that this tax change might be successful. Economic subjects are more perceptive of fiscal changes once they know there is no monetary policy to care about. According to the European Commission (2020), Slovakia in 2018 had the highest implicit tax rate on labour in the EU. It consists of both income and social security contribution taxes, which are the biggest part of this indicator in Slovakia. The difference between Slovakia and Czechia in the implicit tax rate on labour is more than 3 percentage points.

\section{Discussion and Conclusion}

In this paper, we discussed the current condition of public finances in the past 20 years in the Slovak and Czech Republics. We investigated the possible effects of different tax type changes together with the option to cover/offset budget losses. A simple DSGE model of a small economy with three sectors was calibrated for data in 2018. The results of the stochastic analysis showed that the economy was more sensitive to shocks on social security contributions than to those on other taxes. A reduction in labour taxes positively impacted on the economy, which supported the trend of a shift from direct to indirect taxes. The results are in line with previously mentioned works. Múčka and Horváth (2015) studied the effects of increasing taxes in Slovakia and showed that labour taxes are the most harmful to economic growth in the long term. Ambriško et al. (2015) estimated the fiscal multipliers for Czechia and the largest effect occurred with government consumption and social security contributions (paid by employers).

Both countries still have some of the highest labour taxes (consisting of income and social security contribution taxes) in the EU. As calculated by the European Commission (2020b), the implicit tax rate on labour was $43.83 \%$ for Slovakia and $40.61 \%$ for Czechia in 2018, which is the first and the seventh highest rate, respectively, among the EU member states. The tax systems in the two countries are frequently changing. Initially, reforms were 
needed to support the transformation from a centrally planned economy, and then to meet harmonization criteria after joining the EU, but mostly in order to support the economy. Figures 5 and 6 show the important tax rates in the Slovak and Czech Republics and their development over the past 20 years. From 2004 to 2012, Slovakia had one basic flat rate at $19 \%$ for personal, corporate income and value added taxes.

\section{Figure 5: Changes in tax rates over time in Czechia}

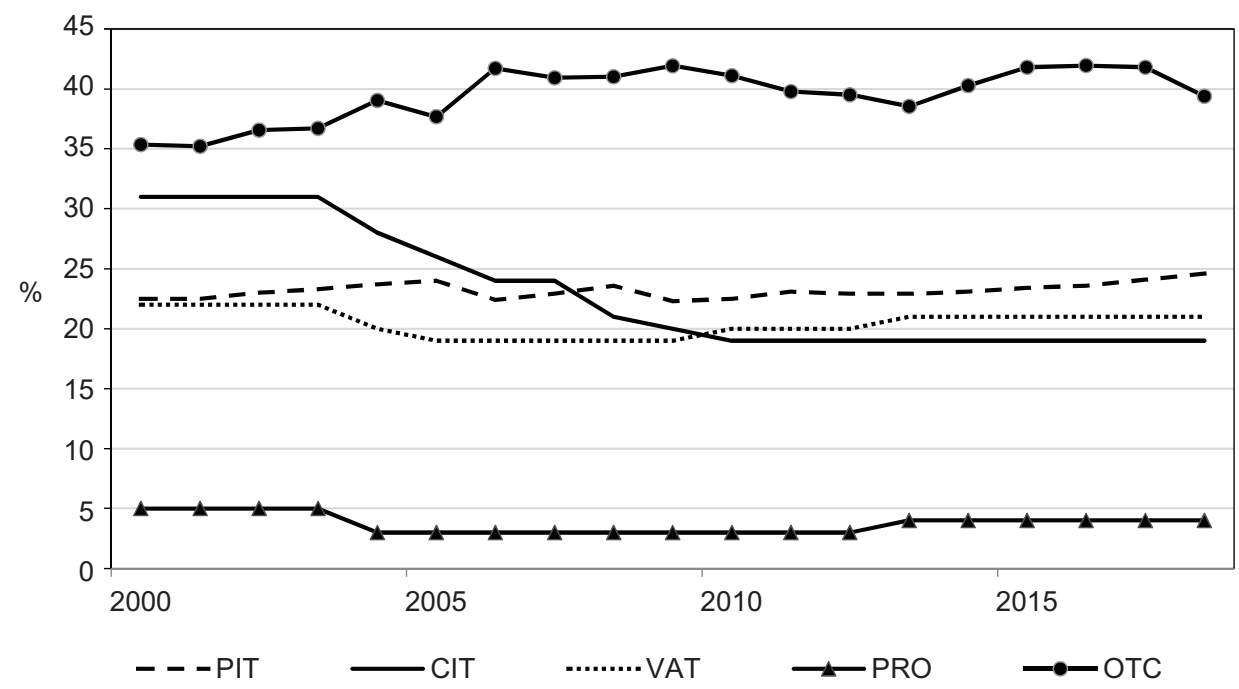

Source: Based on data from the OECD (2020)

Both governments focused mostly on indirect taxes - increasing excises (other taxes on consumption - OTC) ${ }^{1}$ and keeping the basic value added tax (VAT) quite stable. The other area of focus was the corporate income tax (CIT) with a gradual decrease over time. The personal income tax (PIT), consisting of the labour income tax and social security contributions, was left without significant reform, changing only $+/-2$ percentage points around the average, with an increasing trend over time. As supported by our analysis, there is much room for improvement as changes in labour taxes may invoke economic growth. Property taxes (PRO) in both countries are not significant and have low rates at the national level.

1 Excises (OTC) are not standard ad valorem taxes, but mostly unit taxes. The representative tax rate for the OTC category was calculated as the weighted average of the equivalent ad valorem taxes (a percentage of excise on the average annual price). The weights were taken from the Harmonised Index of Consumer Prices published by Eurostat (2020a). 


\section{Figure 6: Changes in tax rates over time in Slovakia}

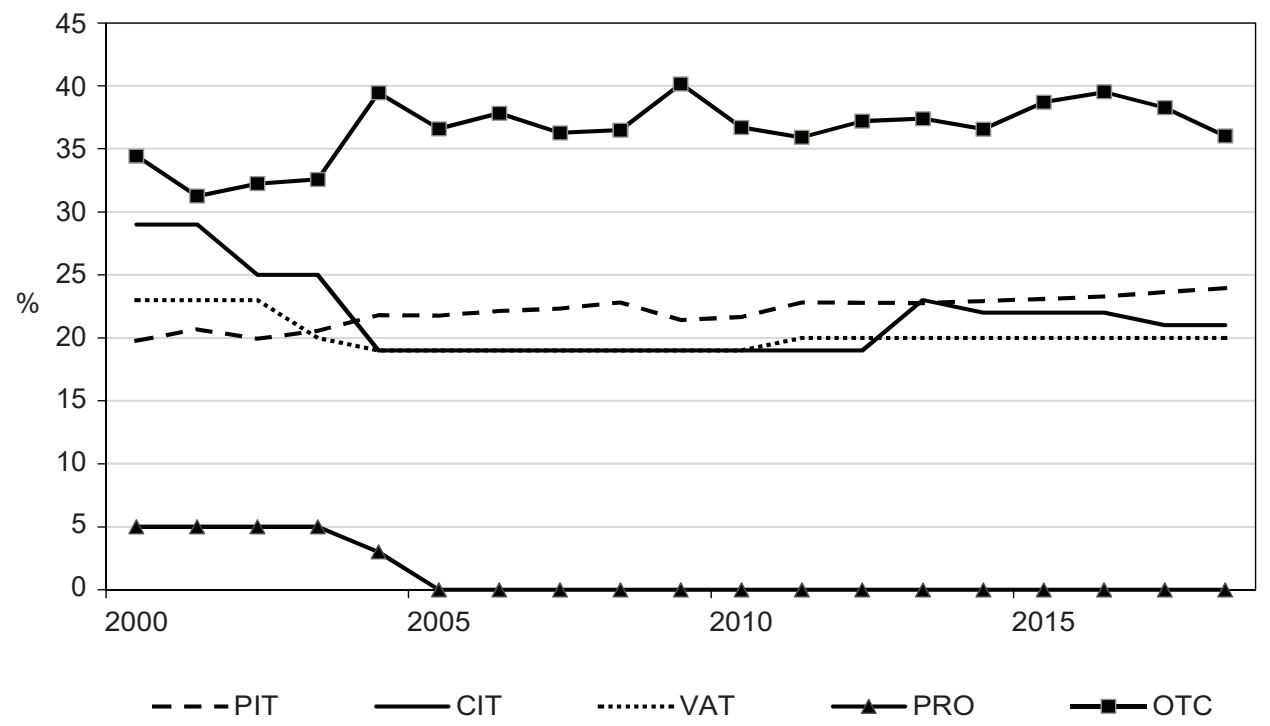

Source: Based on data from the OECD (2020)

A reduction in the income labour tax is one of the tax reforms promised and currently implemented by the Czech government, but, as we have shown, it should rather focus on the social security system as part of labour taxes. It must be noted that the largest part of social security contributions in Slovakia and Czechia are paid in quasi-indirect form by employers but shown to employees as part of their payslip. It would be interesting for future research to extend the analysis to distinguish between social security contributions paid by employees and employers.

Of course, our approach has its limitations, which should be considered when interpreting the results. As every model, it is only a simplification of the reality. The chosen model is a closed economy model, while Slovakia and Czechia are both small open economies; hence, it does not reflect the effects of exchange rates. It describes only the basic relations and should be adjusted for future research by applying different approaches to the pension system or debt creation.

It does not address the possible changes in consumers' behaviour and their saving strategies due to, e.g., increased uncertainty, changing interest rates or government reforms. The model does not allow investigation of the specific characteristics of tax systems (deductibility, progressivity) and should be extended by other types of taxes to better reflect the real tax impact. In order to compare two countries with different monetary 
policy setup, the model is also limited in capturing all the specifics of the monetary union for the Slovak case.

\section{Appendix}

\section{Calibrated parameters}

\begin{tabular}{|c|c|c|c|}
\hline \multirow{2}{*}{ Parameter } & \multicolumn{2}{|c|}{ Value } & \multirow{2}{*}{ Source } \\
\hline & SK & CZ & \\
\hline$a$ & 0.330 & 0.330 & Němec (2013) \\
\hline$\beta$ & 0.990 & 0.990 & Němec (2013) \\
\hline$\delta$ & 0.025 & 0.025 & Costa Jr. and Sampaio (2014) \\
\hline $\boldsymbol{\sigma}$ & 2.000 & 2.000 & Němec (2013) \\
\hline$\psi$ & 3.000 & 3.000 & Němec (2013) \\
\hline$x$ & 0.100 & 0.100 & Costa Jr. and Sampaio (2014) \\
\hline $\boldsymbol{\theta}$ & 0.600 & 0.600 & Němec (2013) \\
\hline$\varphi$ & 6.000 & 6.000 & Costa Jr. and Sampaio (2014) \\
\hline$\omega$ & 0.272 & 0.273 & ČSSZ (2020) \\
\hline PEN & 0.124 & 0.122 & Eurostat (2020d) \\
\hline $\boldsymbol{\tau}_{c}$ & 0.173 & 0.201 & European Commission (2020b) \\
\hline$\tau_{k}$ & 0.139 & 0.192 & European Commission (2020b) \\
\hline $\boldsymbol{\tau}_{1}$ & 0.083 & 0.096 & European Commission (2020b) \\
\hline$\tau_{p}$ & 0.355 & 0.301 & European Commission (2020b) \\
\hline
\end{tabular}

Source: Author's construction

\section{References}

Algozhina, A. (2012). Monetary and Fiscal Policy Interactions in an Emerging Open Economy:

A Non-Ricardian DSGE Approach. CERGE-EI Working Papers No. 476, htttps://doi. org/10.2139/ssrn.2399689

Aliyev, I., Bobková, B., Štork, Z. (2014). Extended DSGE Model of the Czech Economy. Ministry of Finance. Prague Working Papers No. 1/2014. Dostupné z: https://www.mfcr.cz/en/ about-ministry/research/2014/extended-dsge-model-of-the-czech-economy-36572

Alves, J. (2018). A DSGE Model to Evaluate the Macroeconomic Impacts of Taxation. REM.

Working Papers No. 62-2018, https://doi.org/10.2139/ssrn.3293899

Ambriško, R., Babecký, J., Ryšánek, J., et al. (2015). Assessing the Impact of Fiscal Measures on the Czech Economy. Economic Modelling, 44, 350-357, https://doi.org/10.1016/j. econmod.2014.07.021 
Andrle, M., Hlédik, T., Kameník, O., et al. (2009). Implementing the New Structural Model of the Czech National Bank. Czech National Bank Prague Working Paper No. 2/2009. Dostupné z: https://www.cnb.cz/en/economic-research/research-publications/ cnb-working-paper-series/Implementing-the-New-Structural-Model-of-the-CzechNational-Bank-00001

Costa Junior, C. J., Sampaio, A. V. (2014). Tax Reduction Policies of the Productive Sector and Its Impacts on Brazilian Economy. Dynare. Working Papers No. 036.

Cuche-Curti, N. A., Dellas, H., Natal, J.-M. (2009). DSGE-CH: A Dynamic Stochastic General Equilibrium Model for Switzerland. Swiss National Bank. Zurich Working and Discussion Papers No. 5.

ČSSZ (2020). Česká správa sociálního zabezpečení - Otevřená data, 2020. Praha: ČSSZ [cit. 2020-05-05] Dostupné z: https://data.cssz.cz/-/duchodci-v-cr-krajich-okresech European Commission (2020a). Cyclical Adjustment of Budget Balances. Bruxelles: European Commission [cit. 2021-07-29] Dostupné z: https://ec.europa.eu/info/sites/default/files/ economy-finance/cabb_spring_2020.pdf

European Commission (2020b). Data on Taxation. Bruxelles: European Commission [cit. 2020-05-05] Dostupné z: https://ec.europa.eu/taxation_customs/business/ economic-analysis-taxation/data-taxation_en

Eurostat (2020a). Harmonised Index of Consumer Prices (HICP). Luxembourg: Eurostat [cit. 2020-11-30] Dostupné z: https://ec.europa.eu/eurostat/web/hicp/data/database

Eurostat (2020b). Main GDP Aggregates per Capita. Luxembourg: Eurostat [cit. 2020-05-05] Dostupné z: http://ec.europa.eu/eurostat/web/products-datasets/-/tec00127

Eurostat (2020c). Population by Age Group. Luxembourg: Eurostat [cit. 2020-05-05] Dostupné z: http://ec.europa.eu/eurostat/web/products-datasets/-/tps00010

Eurostat (2020d). Social Benefits (Other than Social Transfers in Kind) Paid by General Government. Luxembourg: Eurostat [cit. 2020-05-05] Dostupné z: http://ec.europa.eu/ eurostat/web/products-datasets/-/tec00026

Galí, J. (2008). Monetary Policy, Inflation, and the Business Cycle: An Introduction to the New Keynesian Framework and Its Applications. Princeton: Princeton University Press. ISBN 9780691133164.

Kim, J., Kim, S. (2018). Welfare Effects of Tax Policy in Open Economies: Stabilization and Cooperation. International Journal of Central Banking, International Journal of Central Banking, 14(3), 347-376.

Konôpková, Z. (2017). Reducing Taxes in Slovakia, in Barton, D., ed., Proceedings of the 7th EACO International Scientific Conference. Split: European Association Comenius - EACO, pp. 55-61. ISBN 978-80-905405-3-8.

Konôpková, Z. (2019). Pitfalls of DSGE Model Approach in Monetary Union. DANUBE: Law, Economics and Social Issues Review, 10(4), 369-382, https://doi.org/10.2478/ danb-2019-0019 
Konôpková, Z. (2020). Tax Changes Effects on the Czech Economy, in Nálepová, V., Uhrova, N., eds., Proceedings of the International Scientific Conference ECONOMIC AND SOCIAL POLICY. Ostrava: Vysoká škola PRIGO, pp. 162-172. ISBN 978-80-87291-27-6.

Kotlán, I., Machová, Z., Janíčková, L. (2011). Vliv zdanění na dlouhodobý ekonomický růst. Politická ekonomie, 59(5), 638-658, https://doi.org/10.18267/j.polek.812

Mamatzakis, E. C. (2005). The Dynamic Responses of Growth to Tax Structure for Greece. Applied Economics Letters, 12(3), 177-180, https://doi. org/10.1080/1350485042000318420

Múčka, Z., Horváth, M. (2015). Fiscal Policy Matters - A New DSGE Model for Slovakia. Council of Budget Responsibility. Bratislava Discussion Paper No. 1/2015.

Němec, D. (2013). Investigating Differences Between the Czech and Slovak Labor Market Using a Small DSGE Model with Search and Matching Frictions. Czech Economic Review, 7(1), 21-41.

OECD (2010). Tax Policy Reform and Economic Growth. Paris: OECD Publishing [cit. 2017-06-25], http://doi.org/10.1787/9789264091085-en

OECD (2019). OECD Economic Outlook No. 106. OECD Economic Outlook: Statistics and Projections. Paris: Organisation for Economic Cooperation and Development [cit. 202010-12], https://doi.org/10.1787/8aa5bebb-en

OECD (2020). OECD Tax Database. Paris: Organisation for Economic Cooperation and Development [cit. 2020-05-05] Dostupné z: https://www.oecd.org/tax/tax-policy/ tax-database/

Pytlarczyk, E. (2005). An Estimated DSGE Model for the German Economy within the Euro Area. Deutsche Bundesbank. Frankfurt am Main Discussion Paper Series 1: Economic Studies No. 33.

Štork, Z., Závacká, J., Vávra, M. (2009). Hubert: A DSGE Model of the Czech Republic. Ministry of Finance. Prague Working Paper No. 2/2009. Dostupné z: https://www.mfcr.cz/en/ about-ministry/research/2009/hubert-a-dsge-model-of-the-czech-republi-36566

Zeman, J., Senaj, M. (2009). DSGE Model - Slovakia. National Bank of Slovakia. Bratislava Working Paper No. 3/2019, pp. 4-37. 